\title{
03
}

\section{THE FEMME FRAGILE AND FEMME FATALE IN THE FANTASTIC FICTION OF MACHADO DE ASSIS A "FEMME FRAGILE" E A "FEMME FATALE" NA FICÇÃO FANTÁSTICA DE MACHADO DE ASSIS}

Jordan B. Jones (BYU) James R. Krause (BYU)

Recebido em 24 jun 2015. Jordan B. Jones - English Teacher at Digital Harbor Aprovado em 21 dez 2015. High School in Baltimore, Maryland. Masters of Arts in Portuguese (Brigham Young University, 2015). Bachelor of Arts in English and Portuguese (Brigham Young University, 2014).

James R. Krause - Assistant Professor of Portuguese and Spanish at Brigham Young University in Provo, Utah. PhD in Spanish and Portuguese (Vanderbilt University, 2010). Masters of Arts in Portuguese (Vanderbilt University, 2007). Masters of Arts in Spanish (Brigham Young University, 2005). Bachelor of Arts in Spanish (Brigham Young University, 2003).

Resumo: Joaquim Maria Machado de Assis encontrase entre os melhores autores de qualquer tradição literária. Uma vez que seus romances são excepcionais, muitos de seus contos acabam por ser ignorados pelos estudiosos, especialmente aqueles que, por alguns, são classificados como sendo "fantásticos". O presente estudo visa preencher tal lacuna, através da análise da caracterização feminina na literatura fantástica de Machado de Assis. À primeira vista, Machado de Assis 
parece seguir arquétipos convencionais ao referenciar personagens femininas como sendo femmes fragiles ou femmes fatales, assim reiterando uma visão estereotipada, até mesmo misógina, das mulheres. Porém, Machado, de forma perspicaz, subverte o pensamento erróneo e chauvinista do século XIX no Brasil através da problematização dos papéis de gênero dentro do domínio do fantástico. Empregamse os conceitos de femme fragile e femme fatale apenas para subverter o pensamento patriarcal sobre o qual são baseados, sutilmente levando os leitores a refletirem e reconsiderarem as já estabelecidas percepções de gênero.

Palavras-Chave: Machado de Assis; Fantástico Machadiano; Femme Fragile; Femme Fatale.

Abstract: Joaquim Maria Machado de Assis, ranks among the best authors of any literary tradition. Because his novels are so exceptional, many of his good short stories have been neglected by scholars, particularly those categorized by some as "fantastic." This study attempts to fill that gap by analyzing female characterization in the fantastic fiction of Machado de Assis. On the surface, Machado de Assis appears to follow archetypal conventions in presenting female characters as either femmes fragiles or femmes fatales, thus reinforcing stereotypical and even misogynistic views of women. Ultimately, however, Machado shrewdly undermines erroneous chauvinistic thinking of nineteenth-century Brazil by problematizing gender roles within the realm of the fantastic. He employs the tropes of the femme fragile and the femme fatale only to subvert the patriarchal thinking upon which they are based, subtly encouraging readers to reflect and reconsider established conventions of gender.

Key Words: Machado de Assis; Machadian Fantastic; Femme Fragile; Femme Fatale 


\section{INTRODUCTION}

Joaquim Maria Machado de Assis, arguably Brazil's most preeminent author, has been studied perhaps more than any figure in Brazilian literature. Within the wide range of critical approaches, however, scholars have undervalued the full complexity of Machado's female characters, which "constitute a dynamic, complex, and too long underrated, perhaps even misconstrued, dimension of his narrative art" (FITZ, 2015, p. 3). In Machado de Assis and Female Characterization: The Novels, Earl Fitz argues that "we have, in a sense, been blinded by the brilliance of his male characters," leading us to overlook his female characters (FITZ, 2015, p. 7). Furthermore, he calls upon readers to reexamine "the implications, aesthetic as well as political, of these still incomplete readings of Machado's novelistic women" (FITZ, 2015, p. 4). In spite of recent efforts to highlight Machado's female characters by Fitz and others, most studies favor Machado's novels at the expense of his short fiction. Just as we have been "blinded by the brilliance of his male characters" we have also been blinded by the brilliance of his novels, as Paul Dixon asserts: "Os contos de Machado de Assis têm sido muito elogiados, mas pouco estudados" (DIXON, 1992, p. 10). Because Machado's novels are so exceptional, many of his excellent short stories have been neglected, particularly those categorized by some as "fantastic."

This study attempts to fill that gap by analyzing female characterization in the fantastic fiction of Machado de Assis. ${ }^{1}$ analyze his female characterization. Two recent studies that examine female characters in specific stories, but not the entirety of Machado's fantastic fiction, are Isabel Cristina Hentz's "Filhos legítimos da ciência" and Adriana da Costa Teles's "Viver e morrer de amor em 'O anjo das donzelas.'” 
On the surface, Machado de Assis appears to follow archetypal conventions in presenting female characters as either femmes fragiles or femmes fatales, thus reinforcing stereotypical and even misogynistic views of women. Ultimately, however, Machado shrewdly undermines erroneous chauvinistic thinking of nineteenth-century Brazil by problematizing gender roles within the realm of the fantastic. He employs the tropes of the femme fragile and the femme fatale only to subvert the patriarchal thinking upon which they are based, subtly encouraging readers to reflect and reconsider established conventions of gender.

\section{APPROACHING THE MACHADIAN FANTASTIC}

Before beginning an analysis of the fantastic in Machado de Assis, we should make it clear that Machado is by no means primarily devoted to the fantastic. Of the approximately two hundred short stories he wrote, only about twenty are commonly considered fantastic in some way. ${ }^{2}$ The bulk of his early work is considered romantic; his later work is mostly realist and contains strong critiques of the wistful ideals of romanticism. ${ }^{3}$

2 Raimundo Magalhães, Jr., includes the following eleven stories in his 1973 anthology Machado de Assis: Contos fantásticos: "O imortal" (1862), "O anjo Rafael" (1869), "O Capitão Mendonça" (1870), "A vida eterna" (1870), "Decadência de dois grandes homens" (1873), "Os óculos de Pedro Antão" (1874), "Um esqueleto" (1875), "Sem olhos" (1876), "A mulher pálida" (1881), "A chinela turca" (1882), and "A segunda vida" (1884). In his 2003 study "Machado de Assis: Quase-macabro," Marcelo J. Fernandes adds several more stories to this list: "O país das quimeras" (1862), along with its rewrite, "Uma excursão milagrosa" (1866); "Rui de Leão" (1872, a rewrite of his 1862 story "O imortal"), "O anjo das donzelas" (1864), "Mariana" (1871 version), "A chinela turca" (1875 version), and "Um sonho e outro sonho" (1892) (2003). Braulio Tavares includes the story "As academias de Sião" to his 2003 collection Páginas de sombra: Contos fantásticos brasileiros. Darlan de Oliveira Gusmão Lula includes all of the previously mentioned stories (whether in their first or second versions) in his master's thesis Machado de Assis e o gênero fantástico: Um estudo de narrativas machadianas (2005). Other stories that many have studied within the fantastic mode include "Uma visita de Alcibíades" (1876), "O espelho" (1882), "A igreja do diabo" (1884), and "A causa secreta" (1885).

3 In addition to criticizing romanticism, Machado's realist works condemn the pseudo-scientific thinking of naturalism, the literary movement many of his contemporaries embraced after realism. 
But despite the relatively small portion of his work associated with the fantastic, understanding how Machado engaged with these ideas will enhance our understanding of the nineteenthcentury beginnings of the fantastic in Brazil and its evolution after his lifetime.

In his essay "A nova geração," Machado de Assis (1879) writes: "a realidade é boa, o realismo é que não presta para nada." Machado's frequent recourse to non-realist elements in his stories suggests that he feels constrained by realist techniques and views them as incapable of representing all he wishes to convey in his writing. In Fantasy: The Literature of Subversion, Rosemary Jackson posits that the fantastic "takes the real and breaks it" (JACKSON, 1981, p. 20). Accordingly many texts have fantastic elements, despite their not being exclusively fantastic. The deceased narrator of Memórias Póstumas de Brás Cubas is just one example of how Machado sometimes diverges from realist techniques. Cristina Ferreira-Pinto's comment supports this interpretation: "What matters in Machado de Assis's... novels - are not so much the facts, but rather, how they are narrated" (FERREIRA-PINTO, 2004, p. 30). This same principle applies to his short stories, in which fantastic elements often appear: many of the narrated events never happen in reality; rather, they happen in the narrator's mind.

In attempting to determine what constitutes the Machadian fantastic, this study follows Batalha's suggestion: "Mais prudente seria considerarmos o conceito em seu plural "fantásticos'" (BATALHA, 2011, p. 18). According to some researcher a fewof Machado de Assis's short stories qualify as 
fantastic, to which Marcelo Fernandes responds: "nos contos fantásticos machadianos, não há a justificativa/explicação para os 'fenômenos' narrados; são dissolvidas, quase sempre, pelo simples despertar da personagem" (FERNANDES, 2003). Here we caution readers not to constrain their understanding of the fantastic to Tzvetan Todorov's strict limitations. ${ }^{4}$ Moreover, we appeal to Eric Rabkin's suggestion that we "consider narratives as arrayed along a continuum, ordered in terms of increasing use of the fantastic" (RABKIN, 1976, p. 28). Thus, some of the Machadian stories analyzed in this study ("Sem olhos," for example) may appear more fantastic than others (such as "A cartomante"). Using a variety of stories from different points along this continuum facilitates a deeper understanding of Machado's fantastic and how Machadian women function within this genre.

\section{MACHADO'S FEMME FRAGILE}

In several of his fantastic short stories, Machado de Assis follows nineteenth-century European literary conventions in portraying women. According to Friederike Emonds, the femme fragile embodies "morbid fragility and sickliness, on one hand, and decorative artificiality and sterile beauty, on the other" (EMONDS, 1997, p. 165). Moreover, the femme fragile often displays childlike naiveté in her inability to face the harsh realities of life (EMONDS, 1997, p. 165). In Figuras femininas em Machado de Assis, Ingrid Stein further explains:

4 Bulgarian-French critic Tzvetan Todorov defines la fantastique as "that hesitation experienced by a person who knows only the laws of nature, confronting an apparently supernatural event" (TODOROV, 1975, p. 25). Todorov argues that this hesitation, if explained by natural laws, fits into the category of l'etrange; if not, it belongs to I'merveillux. 
Na literatura europeia do final do século XIX encontra-se com frequência um tipo de figura feminina caracterizado exteriormente pela suavidade, beleza, alvura, quase transparência. Trata-se de um ser frágil, lânguido, melancólico, doentio, necessitado de repouso e com a força de vontade um tanto paralisada, incapaz para a vida e vindo geralmente a sucumbir a ela: uma figura diáfana, etérea, em relação à qual igualmente não se fazem alusões à sexualidade-questão por demais real para seu delicado mundo... Este tipo de personagem foi denominado femme fragileem oposição a outro, muito difundido na literatura europeia do final do século passado, a femme fatale, este ligado à vida, aquele mais à morte (STEIN, 1984, p. 112).

Although Stein focuses primarily on the femme fragile in Machado's novels, including Raquel in Ressurreição and Flora in Esaú e Jacó, her observations also apply to female characterization in Machado's fantastic short stories, in which Machado describes women subjugated to the patriarchal impositions of Brazilian society. Their weakness and death - often the result of male oppression - contrasts sharply with the strength and vitality of men. An analysis of these Machadian femmes fragiles, however, reveals that their male counterparts often succumb to the same naïve thought processes and encounter tragic consequences as a result. Furthermore, many female characters prove to be more logical than their male companions, thus undermining the patriarchal illusion of male superiority that permeated nineteenthcentury Brazil and revealing the need for social change. 


\subsection{WOMAN AS FOIL FOR RATIONAL MAN}

One of the most prominent manifestations of the femme fragile stereotype in Machado's fantastic stories is the juxtaposition between a woman's superstitious credulity and the logical rationality of her male counterpart. In "O anjo das donzelas" and "A cartomante," as just two of several examples, female characters make choices based on superstitious beliefs, thus provoking patronizing and condescending disapproval from their male companions. Whereas Machado portrays women as ingenuous and irrational, he presents men as models of rational thought. Despite the apparent rift between male rationality and female credulity, however, a careful reading reveals that both men and women adopt either superstitious or reasonable viewpoints to support their desired belief systems. Moreover, the male characters in Machado's stories - and by extension Brazilian society - are often the source of the superstitions they so emphatically denounce.

In "O anjo das donzelas", the young and beautiful Cecília dreams an angel appears to place her under a vow of celibacy. The angel presents her with a ring as a reminder of her commitment, with strict instructions never to remove it. Over the years she honors her vow and develops a "terror invencível" of falling in love and marrying, turning down suitor after suitor (MACHADO, 1864). As an old woman, her cousin Tibúrcio visits and reveals that years before he had the ring placed on her finger while she slept. She removes it only to discover Tibúrcio's inscribed initials, learning she had believed in a fantasy her entire life. 
According to Darlan Lula, the covenant with the angel is only possible because Cecília's spirit is "impregnado de sujeições supersticiosas e de crenças no sobrenatural, contribuindo para isso as suas constantes leituras de novelas que a levavam para um outro mundo, imaginativo e fértil" (LULA, 2005, p. 59). Her deeply held belief in the angelic visitation blinds her to reality. Even her name holds symbolic value. As Adriana da Costa Teles explains, "Cecília" shares the same root with the Latin caecus, which means "blind." Teles continues:

Cecília, enquanto donzela romântica e ingênua, como é caracterizada, é, antes de qualquer coisa, uma cega para com os fatos da vida e do mundo, reclusa que está em sua alcova a fazer leituras que a conduzem a uma visão romantizada da vida. (TELES, 2013, p. 163-164).

Cecília's constant reading of romantic novels fills her head with idealized notions and blinds her to the fact that the angel was nothing more than an invention of her credulous mind. As a result, she rejects all who try to court her and misses many opportunities to receive the happiness she so desperately desires. Cecília replays the vision repeatedly in her mind, trying to find comfort and reassurance in her devotion to the vow. Despite her occasional doubts, however, she cannot break free from her superstitious nature and is doomed to loneliness.

Tibúrcio, on the surface, represents intelligent rationality. He provides the logical explanation for Cecília's dream. Even after this explanation, Cecília cannot free herself completely from the superstitions nurtured over the years. When she reveals that she still believes in the angel's visit, Tibúrcio exclaims, "você quer 
contestar uma verdade com uma superstição? Ainda acredita em sonhos!" (MACHADO, 1864). Machado clearly sets up the illogical and credulous Cecília as a foil to her sensible male companion. Had she sought a rational explanation for her supposed vision, Cecília would not have believed in "uma coisa toda de imaginação" (1864). Cecília never fully realizes the misguided nature of her beliefs and never recovers the wasted years of her youth. It seems Machado de Assis reinforces the gullible nature of the femme fragile in what could be perceived as acritique of monasticism. We must remember, however, that Cecília's superstitions originate not from religion but from the fanciful notions she learns from reading romantic novels primarily written by men. In this subtle critique of romanticism, Machado intimates that many times men are the source of the same superstitious behaviors they so harshly criticize when adopted by women.

"A cartomante" narrates the consequences of an adulterous relationship between Camilo and Rita. After a decrease in Camilo's extramarital visits, Rita consults a fortune-teller to assuage her fears. One day Camilo receives a message from Vilela, his best friend and Rita's husband, requesting he visit them immediately. Frightened that Vilela has finally discovered the truth of their affair, Camilo visits Rita's fortune-teller, who ensures him everything will turn out all right. He confidently arrives to Vilela's house only to be shot and killed by his friend, who also just murdered his wife.

In "A cartomante," Rita's superstitious behavior initially contrasts with Camilo's logical actions, but ultimately he falls prey to the irrationality he so strongly condemns. Near the beginning of the story, Rita discusses her visits to the fortune-teller and 
Camilo belittles her for this superstitious practice. He asks, "Tu crês deveras nessas coisas?" (MACHADO, 1884). Camilo, who takes pride in his logical nature, looks down on Rita and out of pity decides not to "arrancar-Ihe as ilusões" (MACHADO, 1884). Lula explains how Rita's beliefs contrast with Camilo's logical thoughts and represent the erroneous thinking of women:

A superstição e a religião são ensinamentos atribuídos à mãe. No momento em que Camilo se livrou da sua influência e foi beber em outras fontes tais como o ensino acadêmico, colocou todas as suas lições "na mesma dúvida" e em seguida "em uma só negação total". Está completo na figura de Camilo o ciclo de pensamento que o homem perfaz, chegando à racionalidade. Machado parece sugerir que a percepção do homem àquela época é diferente da percepção da mulher, envolvida em condicionamentos supersticiosos. (LULA, 2005, p. 61).

In Camilo's view, superstition and religious beliefs are passed down from generation to generation through the mother. No longer a child, Camilo embraces a form of apathetic agnosticism. He no longer believes in religion or superstition, but he also does not actively disbelieve. When confronted with "mistério" he shrugs his shoulders and carries on. Having arrived at rationality through education, Camilo frees himself from the chains of female superstition. Rita, on the other hand, remains shackled to them her whole life, readily accepting the supernatural.

One of the ironies of "A cartomante" is that Camilo, who places so much importance on logical thought, ultimately relinquishes his academic training in favor of a superstitious 
worldview he initially learned from his mother. When Vilela summons him, Camilo vacillates between believing and doubting that Vilela has discovered the affair, which mirrors his wavering between believing in reason or the supernatural. It does not take long for his apparent rationality, including the correct conclusion that Vilela has indeed discovered the affair, to erode and give way to blind faith in the fortune-teller's reassuring words. His behavior during the consultation reveals the exact opposite of the trope so strongly developed in the beginning of the story. Instead of the woman acting as a foil for the rational man, in the final scene it is the man whose gullibility stands in sharp contrast to the woman's cunning intellect. The female fortune-teller manipulates Camilo's fears and motivates him to lean in close, "para beber uma a uma as palavras" (MACHADO, 1884). His payment of five times the usual sum reveals the value he places on her affirmations, and as he reflects on them his childhood beliefs return, "lentas e contínuas" (MACHADO, 1884). Camilo's decision to actively embrace and trust the superstitious worldview the fortune-teller inhabits quickly leads him to his deadly encounter with Vilela and undermines the trope developed so convincingly in the first half of the story. While the story presents men as more rational than women, in the end it becomes clear that superstition is not unique to women, and that rationality is not unique to men. Both men and women can adopt naïve ideas, and both can develop a rational approach to life.

In both "O anjo das donzelas" and "A cartomante" men perceive women as inferior in their capacity to think reasonably, 
but Camilo exhibits the same credulous tendencies he criticizes in Rita. In attempting to distance themselves from female thinking, Tibúrcio and Camilo adopt the view of women so prevalent in Machado's time:

Nenhum espírito racional rondava-Ihes as cabeças, pelo contrário, elas recebiam os ensinamentos das mães a serem devotas, crentes na fé, viviam às rodas com as mucamas, ouvindo-lhes fervorosas crenças em manifestações sobrenaturais. (LULA, 2005, p. 60).

Cecília and Rita embody the "weak, helpless, and sickly" nature of the femme fragile (EMONDS, 1991, p. 166). Their "sickly" nature is not the result of physical malady, as is common with other femmes fragiles in literature; rather, it is the result of their irrationality. Machado initially portrays these women as unable to think for themselves and dependent upon patriarchal systems. As a result, the domineering men in their lives ridicule them - Tibúrcio disparages Cecília for valuing superstition over reason and Camilo criticizes Rita for consulting a fortune-teller. Initially, these two stories appear to vindicate a chauvinistic perception of woman as foil for rational man. Fitz concedes that similar conclusions can be drawn from Machado's novels, but he points out that this interpretation is incomplete: "[Machado's] major female characters do serve, in a sense, as foils to many of his male characters. Or, it might be argued, his famous male characters... can be read as foils to his female characters" (FITZ, 2015, p. 205). In the case of "A cartomante," the astute fortune-teller contrasts sharply with the outwardly skeptical but inwardly credulous Camilo. In "O anjo das donzelas", Tibúrcio, as 
well as the romantic writers, prove to be the source of Cecília's ingenuousness, thus undermining the notion that women are the source of superstitious thought. Although Cecília and Rita appear to serve as foils to the rational Tibúrcio and Camilo, Machado de Assis almost always problematizes this aspect of the femme fragile trope by highlighting the suspect behaviors of men who view women with condescension or even contempt. Machado furtively dismantles this aspect of the femme fragile stereotype by suggesting that, as a whole, women are intellectually equal to men. There are certainly individual exceptions to this idea (Cecília being one of the most prominent in Machado's fantastic fiction), but several of Machado's stories reveal that men, too, fall prey to superstition (Camilo being the prime example). The differences in these characters, then, seem more linked to their personalities than to their physiology. Adopting erroneous ways of thinking leads Cecília to a life of loneliness, Camilo to his death, and many others to suffering and unfulfilled desires. These stories clearly criticize superstition and credulousness, but perhaps the most irrational notion they denounce is the assumption that women are by nature inferior to men.

\subsection{WOMAN AS MANIPULABLE POSSESSION}

Another way in which Machado's female characters ostensibly fit into the femme fragile stereotype is through their portrayal as a possession controlled or manipulated by men. Isabel Cristina Hentz writes: "As mulheres eram sempre 'de alguém': filha de fulano, esposa de beltrano..." (HENTZ, 2011). They have no identity without the men to whom they are subjected. This 
view of women is not restricted to his fantastic short stories but also appears in his realist fiction. In Dom Casmurro, for example, Bento authoritatively tells Capitu how much of her arms to show in public, acting as a master with the right to dictate her every move. Another example comes from Quincas Borba, in which Maria Benedita must renounce her independence to please the man who gives her social status, and become, according to Maria Manuel Lisboa, an "object-wife" (LISBOA, 1996, p. 169). In “Missa do galo," Conceição's husband has no qualms about sleeping with another woman, and even though Conceição knows of the affair, she can do nothing about it. Beyond simply appearing in Machado's fiction, this attitude toward women was widespread in nineteenth-century Brazil, in which "a mulher ocupava na família uma posição secundária, inferior à do homem" (STEIN, 1984, p. 23). The woman was responsible for bearing children, keeping the house in order, and receiving her husband's guests. According to Fitz, the Brazilian man of Machado's day was the "absolute, unquestioned master, or 'senhor,' of the family" (FITZ, 2015, p. 10). Though also present in his realist fiction, this view of women as possessions to be dominated and controlled by men finds its most extreme expression in Machado's fantastic fiction. "Um esqueleto" and "O Capitão Mendonça," as just two examples, ascribe value to women based on their beauty, their wealth, or their subservience to male desire. But while these stories portray women as manipulable possessions, they simultaneously reveal male manipulability and expose this merchandising perception of women for what it is: an illusion of control bred by male anxiety. 
In "Um esqueleto," Alberto narrates his strange interactions with Dr. Belém. An eccentric man, Belém convinces Marcelina to marry him, after which he reveals he keeps the skeleton of his late wife in his house. To Marcelina and Alberto's horror, Belém carries the skeleton around with him and eventually runs off into the forest, after accusing Marcelina and Alberto of betraying his trust and telling them to get married. ${ }^{5}$ Belém's first wife - the skeleton referred to in the story's title - is certainly a possession incapable of acting for herself. Alberto first sees it resting in a glass case, suggesting Belém views his former wife as a trophy. Belém comments that when Marcelina dies he will place her skeleton beside his first wife's, which further illustrates his twisted view of women. In the dinner scene, the skeleton is seated "com os braços sobre a mesa" (MACHADO, 1875). In order for her to be in this position, Belém must physically manipulate her bones. She has no power in and of herself and only moves when Belém maneuvers her. He also attempts to control Marcelina in a similar way, although he controls her through fear rather than physical manipulation. The revelation that he killed his first wife, mistakenly thinking she had been unfaithful to him, reflects an attitude in which the man assumes he can punish the woman as he likes. Indeed, Belém keeps the skeleton around partially so that Marcelina never forgets "seus deveres" (MACHADO, 1875). Although he regrets killing his first wife, who ultimately was innocent of any wrongdoing, he assures his new wife that should he ever suspect her of infidelity he will not seek confirmation of 5 This story falls on the gothic end of the fantastic spectrum. Belém's interactions with the skeleton, although grotesque, are not impossible. However, that Machado is invoking the fantastic mode is evident by the narrator's comment as Alberto begins his story: "Estava-se em pleno Hoffmann." 
his suspicions: "farei justiça por minhas mãos" (MACHADO, 1875). Stein provides insight into this mentality stating that from 1603 until 1830 Brazilian law allowed for a husband to kill his wife due to infidelity. ${ }^{6}$ Although this story presumably takes place several decades after the law was changed, the patriarchal sentiments reinforced by this law were certainly still alive and well. Stein adds: "O adultério masculino é determinado pela existência comprovada de uma 'concubina teúda e manteúda', bastando para o feminino, com base no texto vago da lei, nada mais que 'indícios'”' (STEIN, 1984, p. 29). This uneven treatment of male and female infidelity permeated Brazilian society as a whole, allowing husbands to punish their wives with no substantiated proof of adultery. ${ }^{7}$ Influenced by these ideas, Belém threatens Marcelina in an attempt to force her into submission and mold her into the obedient wife he desires. Whenever Marcelina interacts with him she shows her disgust and unwillingness to comply, but she never dares refuse, fearing Belém's retribution.

The final scene of the story highlights Belém's view of women as manipulable possessions and, at the same time, reveals the inadequacy of portraying them as such. Before vanishing into the woods with the skeleton with no thought of honoring his marital vows, Belém simply passes Marcelina off to Alberto as if giving him a donation. Having relinquished his most recently acquired "possession," Belém feels no more responsibility to support her. His decision to devote his life to the skeleton rather than 6 This comes from the legal code Ordenações Filipinas, originally instituted by Filipe II of Spain during the Iberian Union (1580-1640) and enforced until 1830. Brazil was of course a Portuguese colony until 1822, and was technically subject to Portuguese law.

7 Similar treatment of the supposedly unfaithful wife appears in "O anjo Rafael" and Dom Casmurro. Whereas Belém kills his unfaithful wife, in these stories the wife is banished, constituting a figurative murder as the husband removes her from his life and support forever. 
to his living wife reveals something important about Belém: he recognizes that the completely submissive woman is nothing more than an illusion. He believes that, despite his threats, Marcelina has fallen in love with Alberto. Whether or not this is true is not as important as Belém's perception of the situation. In his mind, his efforts to control Marcelina have failed. Her resistance, however small, challenges the central goal of patriarchal ways of thinking. According to Dixon,

A obsessão masculina é abraçar, possuir, e nunca perder a posse da mulher. E seu maior medo, talvez, seja que ela não se deixe possuir por completo, que se transforme numa substância diferente do que se esperava, que se revele esquiva, inconstante ou fugidia (DIXON, 2006, p. 25-26).

Belém, convinced that Marcelina does not completely submit to his will, chooses the skeleton because he knows that Marcelina - or any other woman, for that matter - will never yield entirely to him, whereas the skeleton will. Only the shriveled form of a woman, with no muscles and no brain, is utterly manipulable. A real woman proves to be "inconstante ou fugidia" (MACHADO, 1875). On the surface, "Um esqueleto" seems to epitomize the manipulable women in the figure of Belém's first wife, but Machado subtly subverts the male desire of total female subservience and reveals that only a pseudo-woman can satisfy the unrealistic expectations of a patriarchal society.

Perhaps the most compelling example of woman as manipulable possession is that of Augusta in "O Capitão Mendonça", in which the perfect, subservient female is not a woman at all, but a product of male ego. In this story, Amaral is approached by 
Capitão Mendonça while at the theater. Mendonça leads Amaral to his house and introduces him to his daughter, Augusta. Proud to show off his daughter's beauty, Mendonça pulls her glass eyes out of her head, revealing that Augusta is in fact an automaton. Although frightened by Mendonça, Amaral is enamored of Augusta and returns to their house day after day. Telling Amaral that he is not yet worthy of his daughter's hand, Mendonça explains that he will surgically insert a chemical mixture into his brain, turning him into a genius and thus making him eligible to marry her. When Amaral resists, Mendonça immobilizes him and bores open his skull. The story ends when Amaral awakens and learns that it was all a dream. ${ }^{8}$

In this story, which explicitly mentions and resembles E. T. A. Hoffmann's "The Sandman" (1816), Augusta has no identity aside from being a creation of Capitão Mendonça. Her relationship with him provides further evidence of her status as manipulable possession rather than independent woman: "Via-se bem que o amor era realçado pelo orgulho; havia no olhar do capitão uma certa altivez que em geral não acompanha a ternura paterna. Não era um pai, era um autor" (emphasis added) (MACHADO, 1870). Augusta's history also reinforces this relationship. Mendonça explains that the Augusta sitting before Amaral is the fourth of his attempts to create the perfect woman. Unsatisfied with the first three products, Mendonça simply reduced them to their "estado primitivo" and tried again (MACHADO, 1870). He dismantled the

8 His behavior at the very end of the story shows that men can be just as superstitious as women. Although Amaral knows the real Mendonça is not the one from his dream, he cannot overcome his superstition and consequently ignores Mendonça's invitation to visit him. The effects of his credulity are not as pronounced as those of Cecília's in "O anjo das donzelas," but the subjection of rational thought to superstition is the same. 
third Augusta because she was not vain enough for Mendonça's liking. The idea that women can be melted down and reshaped by a skilled artisan is nothing short of viewing women as possessions that can be manipulated, undone, and reshaped at will by male intellect and genius.

Mendonça is very proud of Augusta - not for her being an independent woman but for being living proof of his brilliance. Laura Marafante, in a study comparing this story with Hoffmann's, calls attention to Augusta's power to express herself as evidence of her autonomy. She claims that Hoffmann's automaton, Olimpia, more fully represents the stereotypical woman of Machado's period: "comedida, calada, manipulada" (MARAFANTE, 2014, p. 7). After all, it is Augusta, not Mendonça, who states that Amaral needs to be a genius to be worthy of her love. However, Mendonça's wording when explaining this to Amaral reveals Augusta's lack of genuine independence: "Trata-se de uma condição lembrada por minha filha" (emphasis added) (MACHADO, 1870). Augusta does not create the condition that Amaral be a genius to be worthy of marrying her, she simply reminds Mendonça of what he had already implanted in her. Augusta's words mirror the captain's own vanity, carefully programmed in her. Although Augusta gives voice to what we perceive to be her own opinions, they originate in Mendonça's mind. This fourth Augusta, constructed more carefully than the others, says exactly what Mendonça would say because her programmed vanity will not allow her to marry a mediocre man. Moreover, if she does not behave according to Mendonça's wishes, he will certainly melt her down and try again, as he did with the previous three Augustas. 
Seeing this final version of Augusta, Amaral comments that she is Mendonça's "obra-prima," to which he simply responds, "Por ora" (MACHADO, 1870). He then explains that he plans to create "coisas mais pasmosas" (MACHADO, 1870). Mendonça does not view Augusta with paternal love; rather, he views her as an object to be refined and improved. Mendonça is not the only one who shares this view, however. Amaral himself adopts this perception of her: "Augusta era... um produto de arte; o saber do autor despojou o tipo humano de suas incorreções para criar um tipo ideal, um exemplar único" (MACHADO, 1870). Against his better judgment, Amaral returns to their house day after day, feeding his infatuation with Augusta. In this respect, Augusta manipulates Amaral to the same extent that Mendonça manipulates his daughter. Amaral admires the captain's daughter not because she is human, but because she is perfect, as a result of Mendonça's manipulation. ${ }^{9}$ Like "Um esqueleto," this story suggests that the patriarchal conception of the ideal woman in is not a woman at all. Capitão Mendonça, dissatisfied with human women because of their independence, is only happy when he creates a woman who acts according to his desires. That he must create an automaton before considering her a perfect "woman" reveals that no human woman is as manipulable as men would like to think. Amaral views Augusta in the same way, seeing her as more beautiful and perfect than human women because she

9 A similar sentiment is expressed in "Bagatela" (1859), this time by the female character. Like "Um esqueleto," this story resides on the gothic end of the fantastic continuum, containing strange men and mysterious but explainable events. In this story, Max takes in a poor girl named Gabriela and helps her become independent. Gabriela, who was removed from poverty by Max, reveals her own submission to his helpful - but nonetheless condescending-intervention thus: "Eu não sou senão o que me fizeste." Just like Augusta, Gabriela is nothing without her male architect. 
is the product of male imagination. As with "Um esqueleto," the ideal embodiment of the woman as manipulable possession is not a real woman at all but a product of man's ego.

While the stories analyzed in this section appear to support one of two iterations of the femme fragile, either as a foil for rational man or as a manipulable possession, they subtly call attention to the illusion of male supremacy and suggest that the stereotypical, irrational, manipulable woman is nothing more than a fantasy perpetuated by a threatened patriarchal society seeking to retain its power.

\section{MACHADO'S FEMME FATALE}

According to Gail Finney, the femme fatale image is "as old as literature," Helen of Troy being one of the first (FINNEY, 1991, p. 51). Sabine Hake also includes Medusa, Lilith, Delilah, Judith, and Salome in this category $(1997$, p. 164). Usually the femme fatale is portrayed as a "mysterious, enigmatic, and exotic" female who stimulates male desire but does not satisfy it (FINNEY, 1991, p. 51-52). These figures often seduce men and lead them to suffering and death, with no possibility of escape. Perhaps the most famous femme fatale in Machado's fiction is Capitu, whose alleged infidelity destroys Bento Santiago's happiness and pushes him to a solitary, miserable life. Careful analysis of Machado's fantastic short stories will show, however, that beyond threatening the existence of individual men, the femme fatale signals the demise of a whole system of patriarchal thinking. 


\subsection{WOMAN AS SIREN}

One of the clearest representations of the femme fatale in Machado's fiction is the image of the siren, particularly in "A cartomante" and "O Capitão Mendonça." In these stories, as with sirens in classical literature, the men who fall prey to their captivating power encounter suffering and often death. While the sirens of Greek mythology use their song to seduce, Machado's sirens use something else: their eyes. The power of the female gaze is evident several works of Machado, most prominently in Dom Casmurro, in which Bento Santiago describes the power of Capitu's famous "olhos de ressaca":

Traziam não sei que fluido misterioso e enérgico, uma força que arrastava para dentro, como a vaga que se retira da praia, nos dias de ressaca. Para não ser arrastado, agarrei-me às outras partes vizinhas, às orelhas, aos braços, aos cabelos espalhados pelos ombros; mas tão depressa buscava as pupilas, a onda que saía delas vinha crescendo, cava e escura, ameaçando envolver-me, puxar-me e tragar-me (1889).

Bento feels powerless against Capitu's eyes, and, as the story continues, he is captivated - even obsessed - by them. Lisboa asserts that at this point of the novel Capitu is "in full command of her siren song" (LISBOA, 1996, p. 222). Ferreira-Pinto writes that, to Bento, Capitu is "another version of the seductive Eve... a sketch of the powerful Medusa with her dangerous, hypnotizing eyes" (2004, p. 21). And like these siren figures, Bento's reactions to Capitu's gaze eventually leads to his downfall. Similarly, as Eugênio Gomes points out, women's eyes in the Machadian 
fantastic exercise "um papel decisivo e mesmo tirânico de sedução amorosa" (GOMES, 1967, p. 99). The encounters between men and women in these stories almost always include suffering or death. Nevertheless, far from being driven by bloodlust or sadism, these women are motivated - whether consciously or not - by a survival instinct. In a patriarchal society that strips women of every other power and opportunity, seducing men is one way in which they can challenge the myth of male superiority and improve their situation.

In "A cartomante," Rita functions as the seductress who leads Camilo to his downfall, her gaze challenging the male-dominated world in which she lives. When Camilo first meets Rita, the wife of his childhood friend Vilela, he notes her beauty and her "olhos cálidos" (MACHADO, 1884). As he and Rita spend more time together, Camilo notices that Rita's "olhos teimosos... procuravam muita vez os dele," even before consulting her husband's eyes (MACHADO, 1884). Like many men encountering sirens, "Camilo quis sinceramente fugir" but is unable to break free of her grasp: "Rita, como uma serpente, foi-se acercando dele, envolveu-o todo, fez-Ihe estalar os ossos num espasmo, e pingou-Ihe o veneno na boca. Ele ficou atordoado e subjugado" (MACHADO, 1884). Like Adam in the Garden of Eden, Camilo struggles in vain against the fatal influence of the Eve figure, corrupted by the serpent's deception. Entangled in her monstrous grip, Camilo continues his adulterous relationship with her until his death at Vilela's hands. Rita functions as the femme fatale who quite literally leads the man to death, and in this case she dies along with her victim. Rita's fatal seduction is best understood when considering Lisboa's 
comment: "If Machado's portrayal of the monster woman is not uniformly flattering, therefore, nevertheless it always contains an indictment of its probable source, pinpointed as contextual rather than innate" (LISBOA, 1996, p. 259). Rita's behavior, although adulterous, is motivated in part by the restrictions society places on her. Unable to exert influence in healthy ways because of her oppressive environment, she resorts to seduction to assert what little independence she retains. Despite her apparent naïveté, her seductive gaze entraps Camilo and turns the myth of male dominance on its head.

In "O Capitão Mendonça," Augusta's eyes conquer Amaral's heart and lead him to his demise. Upon seeing her "dois belíssimos olhos verdes" (MACHADO, 1870). Amaral studies her more intently, interpreting every gesture as flirtatious and inviting. Like the siren's song, Augusta's eyes draw him in and cloud his judgment, encouraging him to stay in Mendonça's sinister house. At one point Mendonça removes Augusta's eyes to show Amaral the level of craftsmanship. Seeing her grotesque eyeless head causes repulsion, disgust, and horror,but something entirely different replaces these feelings once Mendonça replaces the eyes in their sockets: "Uma sensação nova, que não sei se era amor, se admiração, se fatal simpatia. Quando fitava os olhos dela dificilmente podia afastar os meus" (MACHADO, 1870). When Amaral finally leaves the captain's house, he cannot clear his mind of the "imagem da moça [que] flutuava entre o nevoeiro da [sua] imaginação" (MACHADO, 1870). Much like Capitu's "olhos de ressaca," Augusta's enchantment over Amaral simultaneously pushes him away while drawing him closer ashe finds "[a] fascinação 
do olhar da moça" figuratively intoxicating. When Mendonça describes his plan to bore into Amaral's brain in order to turn him into a genius, the captivated lover pays little attention because his eyes are "embebidos nos de Augusta" (MACHADO, 1870). Had he recognized Augusta's seductive power as an entrapment, he may have avoided his fate. When Amaral finally realizes his plight and contemplates escape, he concedes:

Uma força me prendia, e dificilmente poderia eu arrancar-me dali; era Augusta. Aquela moça exercia sobre mim uma pressão a um tempo doce e dolorosa; sentia-me escravo dela, a minha vida como que se fundia na sua; era uma fascinação vertiginosa (MACHADO, 1870).

Her enslaving power leads Amaral to his downfall. The gaze of Augusta's captivating green eyes draws Amaral back to Mendonça's house, against his better judgment, eventually entrancing and paralyzing him as the captain drills into his brain.

As mentioned before, Augusta's identity as automaton creates an image of complete deference to male authority. She is clearly manipulated by Mendonça, but her powerful gaze transforms her into manipulator when interacting with Amaral. Throughout the story both Amaral and Mendonça affirm that Augusta is perfect, exhibiting all the characteristics a woman should have. Curiously, Augusta's power of seduction is her most pronounced trait, revealing the extent to which these men, especially her creator, view women as capable - or incapable - of assuming other roles. If Augusta, the perfect woman according to male standards, is first and foremost a seductress, what options are left for mortal women other than using their beauty to seduce and influence the 
men around them? This story powerfully highlights the chauvinist view that women's value is determined primarily by their sexual appeal. In a society permeated by these notions, it is little wonder that so many of Machado's women become sirens. Rather than condemning this behavior, "O Capitão Mendonça" illustrates how much their patriarchal society has reinforced it.

In both "A cartomante" and "O Capitão Mendonça," women captivate men through the intoxicating power of their sexual gaze, leading them to their demise. However, these women utilize their sexuality as one of the few tools to which they have access in an oppressive patriarchal system. Although the role of siren is not silent or submissive, these stories call attention to its prevalence and suggest that if women were given more access to educational and professional opportunities, they would not have to resort to their powers of seduction to assert their independence. In addition to calling attention to women's limited options in society, this trope is in itself a challenge of patriarchy. Carla Rodrigues writes that the inclusion of the female gaze in Machado's fiction constitutes an "ousadia machadiana." She writes:

Às mulheres de seu tempo não era dado o direito de olhar, privilégio masculino da sedução. Baixar os olhos diante de um homem era a regra social em vigor. Sustentando o olhar para um homem de forma desafiadora, Capitu seria uma mulher de vanguarda; ela não apenas olha Bentinho com amor, mas, sobretudo, usa o olhar como expressão para seduzir e confundir. (RODRIGUES, 2008, p. 62)

In the same way that Capitu's gaze challenges male dominance, the siren figures in these stories use their gaze not 
only to seduce but to confuse. Seduction - represented most commonly through the symbol of the female gaze in these stories - is, according to Regina Chicoski, "uma arma feminina, afinal é o que dá poder à mulher. Assim, o feminino deixa de ser considerado o lado frágil e dominado passando a ser visto como o ser dominante" (CHICOSKI, 2008, p. 2). It is the seductive gaze-whether intentional or unintentional - that allows Machadian women to break free from their role as subjugated, submissive, and manipulable objects, transforming them from femmes fragiles into femmes fatales. While these sirens still function in a stereotypical role, they move toward independence by deconstructing the notion that women are powerless beings destined to be dominated by men. Hélène Cixous discusses the Medusa, a common iteration of the femme fatale in literature: "You only have to look at the Medusa straight on to see her. And she's not deadly. She's beautiful and she's laughing" (CIXOUS, 2003, p. 133). Similarly, in Machado's fantastic fiction the siren figures are beautiful. Although they appear to threaten the entire male sex, they primarily subvert those aspects of the patriarchal system that oppress women. These stories invite readers to "look at the Medusa straight on" in order to see her for what she really is: a woman who is not dangerous, but beautiful and different, and who yearns for equal access to opportunities in society.

\subsection{WOMAN AS FANTASTIC OTHER}

In addition to appearing as sirens, women in Machado's fantastic operate as femmes fatalesby functioning as the fantastic element that challenges male rationality. This is the case in "Sem 
olhos" and "O Capitão Mendonça." While discussing how females relate to the fantastic, Cynthia Duncan writes:

Because male narrators are attempting to carve out a gendered subject position from which they can tell the story, the female characters are pushed into the role of Other, representing not only difference but also danger. (DUCAN, 2010, p. 244).

She explains that men designate women as "Other" when they fail to comprehend or accurately describe them (DUNCAN, 2010, p. 135). When confronted with the apparently supernatural qualities of women, Machado's male narrators feel threatened and respond by thrusting them into the realm of the incomprehensible other, the dangerous femme fatale who "never really is what she seems to be" (DOANE, 1991, p. 1). Viewed in this way, women seem to be diametrically opposed to men, embodying that which cannot be explained and therefore representing danger. In other words, when a woman is identified as other, she acts as a femme fatale who exceeds the bounds of male reason and rationality and threatens to undermine patriarchal superiority. In Dom Casmurro, Bento views Capitu as a femme fatale who leads him to his downfall by what he perceives as her beguiling and adulterous behavior. While her alleged adultery remains questionable, Capitu's representation as dangerous permeates the novel as well as much scholarly criticism, stemming initially from José Dias's negative evaluation and later from Bento's jealous reflections about her. Capitu appears, according to Lisboa, as "independent, unfettered and fearless, different, 'other'"' (DIAS, 1996, p. 222). John Gledson posits that "Capitu cannot be 'explained', if by that 
we mean reduced to one or other of the false alternatives which a simplistic social or emotional version of human psychology might propose" (1984, p. 72). Because she defies categorization, Capitu embodies a dangerous incomprehensibility to men. Likewise, in "O Capitão Mendonça" and "Sem olhos" the male characters" perception of women is similar to Bento's image of Capitu. The fantastic femme fatale challenges and dismantles reason and logic, thus undermining the entire system of patriarchy. Both the natural and supernatural femmes fatales point to "otherness" in that they defy male comprehension. In this way, these fantastic female "others" challenge male conceptions of reality and expose how men reject women who do not satisfy patriarchal expectations.

In "O Capitão Mendonça," Augusta represents the fantastic other in her incredible origins and in her absolute perfection, while at the same time exposing the "otherness" of natural women. Until Augusta enters the story, Amaral's interactions with Mendonça seem totally possible, even if perhaps a little mysterious. But when Mendonça holds "os dois belos olhos da moça" in his hand after removing them from her head, Amaral is confronted with the fantastic (MACHADO, 1870). This effect is compounded when Amaral notices that Augusta's eyes, even when removed from her body, are still fixed on him: "Separados do rosto, não os abandonara a vida; a retina tinha a mesma luz e os mesmos reflexos" (MACHADO, 1870). Augusta's supernatural green eyes retain their capacity to process what is happening, causing Amaral to question what is real:

A menina era realmente um produto químico do velho? Ambos mo haviam afirmado, e até certo 
ponto tive a prova disso. Podia supô-los doidos, mas o episódio dos olhos desvanecia essa ideia. Estaria eu ainda no mundo dos vivos, ou começara já a entrar na região dos sonhos e do desconhecido? Só a fortaleza do meu espírito resistiu a tamanhas provas; outro, que fosse mais fraco, teria enlouquecido. E seria melhor. $\mathrm{O}$ que tornava a minha situação mais dolorosa e impossível de suportar era justamente a perfeita solidez da minha razão. Do conflito da minha razão com os meus sentidos resultava a tortura em que me eu achava; os meus olhos viam, a minha razão negava. Como conciliar aquela evidência com aquela incredulidade? (MACHADO, 1870).

Amaral experiences the hesitation Todorov considers so essential to the fantastic. He cannot deny what his eyes have seen, and yet he cannot initially accept what reason tells him is impossible. To him, everything about Augusta represents what cannot be. It is for this reason that he struggles so much to decide whether her alleged "origem misteriosa e diabólica" is real (MACHADO, 1870). In addition to her incredible existence as a "produto químico", Augusta represents the fantasticthe impossible - because she surpasses natural women in her qualities (MACHADO, 1870). Amaral describes her thus:

Augusta era tão bela como as outras mulheres talvez mais bela-, pela mesma razão que a folha da árvore pintada é mais bela que a folha natural. Era um produto de arte; o saber do autor despojou o tipo humano de suas incorreções para criar um tipo ideal, um exemplar único. (MACHADO, 1870).

It is precisely her perfection that places Augusta in the realm of the fantastic. That she sees herself as different from other women becomes apparent when she tells him that "todas as 
outras mulheres são filhas bastardas, eu só posso gabar-me de ser filha legítima, porque sou filha da ciência e da vontade do homem" (MACHADO, 1870).

In her perfection, however, Augusta reveals the "otherness" of natural women, whom men cannot simply melt down and reshape at will. The fantastic femme fatale defies categorization and represents unknown ability in male eyes. Augusta has been purified of the "incorreções" of natural women, which are what Amaral calls the different and dangerous aspects of female nature. Augusta's self-identification as daughter of the "vontade do homem" reveals that she is nothing more than the product of patriarchal projections of what constitutes the perfect woman. In this case both Amaral and Capitão Mendonça prefer an artificial automaton to a human woman. Natural women are unfathomable and threaten their illusion of superiority. It is precisely Augusta's perfection that highlights the unknown ability of fallible, but real, women in their eyes. Hentz highlights the fact that Machado's female character resides "fora dos modelos femininos do período" (HENTZ, 2011). She posits that Augusta's artificial nature authorizes her to "transgredir os papéis sociais atribuídos às mulheres em seu período" (HENTZ, 2011). In both her behavior and her appearance, Augusta subverts reality by challenging the natural limits of femininity. In this patriarchal society, only an artificial woman is permitted to break free of male expectations. This calls attention once more to the oppressive conditions in which nineteenth-century Brazilian women lived. As with the other characters analyzed in this study, Augusta does not explicitly criticize gender relations in Brazil; rather, by personifying 
chauvinist conceptions of the ideal woman, Augusta exposes the patriarchal pipe dream of male control and female subservience as an impossible and cancerous myth.

In "Sem olhos", Cruz recounts of his encounters with Damasceno, his half-crazy neighbor. After a few conversations, Damasceno relates a tragic story to Cruz. Damasceno fell in love with the married Lucinda,noting how she always avoided looking into his eyes for fear of falling in love with him as well. When she finally looks longingly into Damasceno's eyes, her jealous husband discovers them and, as a form of punishment, burns out her eyes. On the night Damasceno dies from illness, Cruz sees Lucinda's ghost, an image that haunts him for the rest of his life.

Lucinda's ghost transgresses the bounds of reality and calls attention to how men punish insubordinate, "other" women. When Damasceno first sees Lucinda's ghost, it is not clear whether or not he is simply hallucinating, especially since his other interactions with Cruz suggest he is mad. But Cruz, a judge - the embodiment of rationality - also witnesses the awful specter of Damasceno's love: "De pé, junto à parede, vi uma mulher lívida, a mesma do retrato, com os cabelos soltos, e os olhos... Os olhos, esses eram duas cavidades vazias e ensanguentadas" (MACHADO, 1876). He remarks that, faced with this apparition, "senti esvaírem-se-me as forças e quase a razão" (MACHADO, 1876). Lucinda's ghost, a lingering shadow of the real Lucinda, directly challenges Cruz's logical explanations. The fantastic element of the story becomes even more powerful when he reveals that Damasceno's story was another of his deranged illusions, "uma simples invenção de alienado" (MACHADO, 1876). Although Cruz cannot explain how 
or why he saw Lucinda's eyeless face, he staunchly affirms that he indeed saw her apparition. His hesitation in the face of the supernatural haunts him for the rest of his life. And because he gives no reason to doubt his story, the same hesitation persists in the reader after the story ends. ${ }^{10}$ Lucinda's appearance constitutes a femme fatale who threatens the solidity of male certainty. The most horrifying aspect of Lucinda's ghost is her bloody eye sockets, a gory reminder of how her husband punishes her for the illicit glance that reveals he does not control her as completely as he thinks. His revenge is an immature response to the discovery that Lucinda is "other" - Lucinda's imperfect submission to his authority constitutes a threat to his power. Unable to live with this frightening prospect, he mutilates her in a final assertion of superiority. Thus, Lucinda's unnatural specter acts as the fantastic element of the story while her natural, human body reflects the brutal subjugation under which many Brazilian women of the time found themselves.

Each of the female characters analyzed embody the femme fatale to some extent, whether as a siren or fantastic other, in that they signify the death or destruction of male authority. They challenge patriarchal views of gender roles and draw attention to the damaging ways in which males respond to these perceived threats. Like Capitu, each of these women remains "um enigma, isto pela impossibilidade de delineá-la e concretizá-la. Por mais que se procure apreendê-la, ela sempre escapa" (STEIN, 1984, p. 105). Such impossibility of comprehending the other is part of 
what constitutes the fantastic in the male narrators' perspective. In these stories, perhaps the most striking concept that escapes their comprehension is true femininity, free from patriarchal impositions. As Anélia Pietrani writes, Machado's women are “personagens consideradas 'assustadoras' aos olhos masculinos. Transgridem os sistemas delimitadores da cultura patriarcal... sendo, portanto, consideradas símbolos da desordem" (PIETRANI, 2000, p. 53). Nevertheless, Mary Ann Doane cautions us not to view the femme fatale as "some kind of heroine of modernity," explaining that she is nothing more than "a symptom of male fears about femininity" (DOANE, 1991, p. 3). The femme fatale challenges male authority to some extent, but she does not represent the full potential of women. In these stories, these figures are not enviable - they are oppressed and shunned by the men around them. Hake explains that, despite her power, the femme fatale "remains a cipher and a chimera, the underside of socially determined constructions of gender" (HAKE, 1997, p. 164). Rather than being celebrated as a heroic figure, the femme fatale - whether she appears as a siren or as a fantastic other - is feared, even hated by those she threatens. She does not choose this role, but rather assumes it "out of circumstantially enforced necessity" (LISBOA, 1996, p. 259). Becoming a femme fatale is arguably the most effective way for a woman to voice her opinions and exert her influence in a male-dominated society, but it is a temporary and untenable solution. It often reinforces misconstrued and imbalanced gender roles. By presenting women as sirens and as fantastic others, Machado does not advocate that Brazilian women should aspire to these roles. He exploits these 
stereotypes to call attention to the diseased nature of patriarchal thought and the need for monumental and systemic change.

\section{SOCIAL CRITICISM IN THE FANTASTIC FICTION OF MACHADO DE ASSIS}

Todorov asserts that fantastic literature is "nothing more than the uneasy conscience of the positivist nineteenth century" (TODOROV, 1975, p. 169). If that is true for Machado's fantastic as well, how do his stories - which at first glance seem blatantly misogynistic - perform this function in the context of gender inequality? If, as Jackson argues, the fantastic is truly focused on the "dissolution of an order experienced as oppressive and insufficient" (JACKSON, 1981, p. 180), can we consider these Machadian stories to be fantastic in their function as well as in their form? On the surface, Machado does not seem to openly condemn the chauvinistic portrayal of women in his stories. In fact, his female characters seem to conform perfectly to Fitz's description of how Machado's women are often interpreted: "less than admirable," "meretricious and fickle," and "presented to the reader in less than sympathetic, even misogynistic, ways" (FITZ, 2015, p. 6). The tropes of the femme fragile and the femme fatale seem to promote these condescending views of women. And with no clear calls for social change, Machado's fantastic fiction seems to reinforce the patriarchal traditions of his time. Despite his apparent sexism, Fitz asserts that the Brazilian master was "fully aware" of the danger of "patriarchal ways of thinking" (FITZ, 2015, p. 8), and that he, "the ultimate craftsman," was not careless in creating his female characters (FITZ, 2015, p. 
194). Gledson likewise cautions us against simplistic readings of Machado: "Não deveríamos pensar, só pela maneira como retrata as mulheres, que Machado julgasse que fossem assim por sua própria natureza" (GLEDSON, 2006, p. 60). Although Machado's works appear to support patriarchy, they contain veiled - yet strong - critiques of gender inequality. While we have demonstrated how Machado discreetly denounces chauvinist ideals in his fantastic stories, we have yet to explain why he disguises his critiques in the first place. Machado de Assis's indirect approach to social criticism was influenced in large measure by the expectations of his readership.

All of the stories used in this study were published in the Jornal das Familias, with the exception of "A cartomante" (published in the Gazeta de Notícias). According to Álvaro Simões Júnior, the Jornal das Famíliaswas directed to a public that was mostly female, "oferecendo-Ihe moda, receitas, conselhos para a vida doméstica e literatura amena, sentimentalista e edificante" (2009, p. 15). This explains in part why Machado nearly always resolved the fantastic elements of his stories he did not want to "maltratar os róseos nervos ou desalinhar as tranças de suas fiéis leitoras" (FERNANDES, 2003). If he included too many fantastic elements, or if he did not resolve most of them, he risked offending his primary audience. In addition to being considerate of women's tastes, however, a more practical explanation exists: the subscription to the journal was paid for by these Brazilian women's husbands. For this reason, Jaison Crestani remarks that Machado had felt himself on a knife-edge. in the sense that he had the "obrigação de não escandalizar o pai 
ou marido que pagava pela assinatura do jornal e, ao mesmo tempo, seduzir a mulher que o lia" (CRESTANI, 2009, p. 68). Regardless of his personal views, Machado needed to please his readers (and their husbands), hence the recourse to indirect rather than blatant criticism of the crippling patriarchal attitudes so prevalent in his day. ${ }^{11}$ Machado may have recognized that one of the most effective ways to achieve social change is not to offer solutions but rather to simply magnify perspectives and systems of thought. This allows readers to draw their own conclusions about the validity of these structures.

In addition to including social criticism in his fantastic fiction, Machado subtly inserts it into his novels as well. For example, Ferreira-Pinto writes that Dom Casmurro portrays the condition of Brazilian women but simultaneously "problematizes that condition through the use of ambiguity and an unreliable narrator, thus inviting the reader to look at it in a critical way" (FERREIRA-PINTO, 2004, p. 26). Just as he does in his fantastic fiction, Machado puts patriarchal society on display for readers to analyze it for themselves. Fitz remarks:

Machado wants his New Reader to do to the text she or he is reading, interpreting, and analyzing exactly what he (Machado) wants this same reader/ citizen to do to her or his society: Think seriously about all this, his texts seem to say to us; consider what is truly going on (slavery, the effects of slavery, and the suppression of women, for example), and decide whether things should continue as they are or be changed and whether a new and more

11 It is also possible that, in addition to protecting his livelihood, Machado veiled his criticism to ensure that his stories would circulate more, thereby reaching more people and subtly planting the idea that patriarchy was a broken system that needed replacing. 
progressive society should be constructed, one which would involve a radical change in the status of Brazilian women. (Fitz, 2015, p. 21-22)

Hopefully, as readers study Machado's realist and fantastic fiction, they will identify unhealthy attitudes and behaviors and feel motivated to correct them. This impetus for social change, if adopted correctly, does not lead readers to "replace one hierarchical structure with another but merely to extend our perceptions as a way of opening a space for those who have been marginalized" (DUNCAN, 2010, p. 44). Thus, Machado's dismantling of patriarchy does not include a call for a woman - dominated society. It simply seeks to broaden readers' perception of gender roles and recognize the problematic attitudes we need to overcome.

Although Machado denounces patriarchy in his realist works, using the fantastic allows him to include exaggerated elements that expose patriarchy in ways not possible in his realist fiction. According to Maria Batalha, he seems to understand that "é através do fantástico que a verdade dos monstros reais que a sociedade e a cultura secretam podem vir à tona" (BATALHA, 2011, p. 19). Indeed, many of Machado's most monstrous figures, who also embody the strongest critiques of patriarchal society, are supernatural, such as the automaton Augusta and Lucinda's ghost. If he had adhered strictly to realist conventions, these women would not appear in his works because they cannot be found in reality. As Machado matured as a writer, he came to view realism as increasingly "superficial," "restrictive," and "inadequate" for his goals as a social thinker (FITZ, 2015, p. 6). Turning to the fantastic allowed him to surpass certain boundaries, exploring alternate ways of thinking and of addressing 
gender issues. The tropes of the femme fragile and the femme fatale also manifest themselves in Machado's realist fiction, but in his fantastic fiction they are exaggerated and quickly identifiable. In his novels, Machado teases and slowly draws out his critiques of patriarchy. In his fantastic short stories, due to limitations of space, Machado must get right to the point in simultaneously presenting and dismantling patriarchal conceptions of women. His liberty to include what lies beyond reality allows him to conjecture what might happen to Brazilian society if chauvinistic ideas propagate. These themes appear in his realist fiction as well, but addressing them through the lens of the fantastic allows him to explore their flaws in starker relief. ${ }^{12}$ Restrained by the limits of reality when writing in the realist mode, Machado turns to the fantastic to magnify the problems of patriarchal thinking and broaden our perspective on gender relations in Brazil.

Machado's recourse to the fantastic constitutes a performance and exaggeration of concepts of gender. His fantastic stories, which are all explicitly or implicitly narrated by men, expose the silencing of women's voices in his time, but without passing final judgment. He never thrusts his views upon his readers, but they are "always there for the careful reader to discern" (FITZ, 2015, p. 5). Machado's presentation of women in his fantastic fiction subtly but clearly brings to light the negative consequences of pigeonholing women into stereotypical roles. Instead of proposing new female stereotypes in these stories, Machado shows how perpetuating

12 The presence of similar tropes and critiques in both his fantastic short stories and his novels may signify that the short stories were trial runs for his novels, constituting his attempt to discover how to incorporate the criticism he wanted without being too blatant about it. It is reasonable to view his short stories, especially his earlier ones, as explorations of themes that he will later expand in his novels. 
old ones leads to suffering and death. The images of the femme fragile and femme fatale help readers recognize that no woman (or man) fits perfectly into any stereotype. Focusing on that fact also helps readers understand that a given story "is not a tale about an actual woman, but a story about the narrator's perception of that woman" (DUNCAN, 2010, p. 134-135). Machado's short stories especially his fantastic ones - are what Dixon calls "some kind of virus" that challenge and problematize binary ways of thinking (DIXON, 1992, p. 109). They draw attention to the problems faced by Brazilian society and motivate readers to view women not as "a single monolithic entity" (FITZ, 2015, p. 97), but as individuals. Through careful inclusion of the fantastic in his short stories, Machado de Assis challenges and subverts readers' conceptions of gender, in hopes of laying bare the inadequacies and inequities of nineteenth-century Brazilian patriarchy.

While we have attempted to fill a gap in Machadian studies by analyzing the major female characters of his fantastic fiction, we fully recognize that the present study does not cover every aspect of Machado's fantastic stories, or even of women in those stories. We echo Raimundo Magalhães Júnior's statement from the preface to Machado de Assis: Contos fantásticos: "Não pretendemos, com estas breves observações, exaurir o estudo dos elementos fantásticos na obra machadiana, isto é tarefa por cumprir, pois a obra machadiana se oferece a múltiplas leituras e muito há ainda por ser dito" (38). We do not claim to have exhausted the theme of women in the Machadian fantastic; rather, we present one of the many "plausible lines of interpretation" (FITZ, 2015, p. 5) available in Machado's fantastic fiction. The multiplicity of possible readings 
is precisely what makes his work resistant to closure and, in the face of attempts to find the "right" way to interpret Machado, renders it truly fantastic.

\section{REFERENCES}

Batalha, Maria. (2011). Introdução: Primeiras conversas. O fantástico brasileiro: Contos esquecidos (p. 9-19). Rio de Janeiro: Caetés.

Chicoski, Regina. (2008). A trajetória feminina entre os Séculos XIX e XX na obra Missa do Galo: variações sobre o mesmo tema. Fazendo Gênero 8: Corpo, Violência e Poder (Conference Presentation). UFSC, Florianópolis.

Cixous, Hélène. (2003). The Laugh of the Medusa. Keith Cohen and Paula Cohen (Trans.). The Medusa Reader. Majorie Garber, William R. Kenan, Jr. (Eds.). New York: Routledge.

Crestani, Jaison Luís. (2009). Machado de Assis no Jornal das Famílias. São Paulo: Nankin.

Dixon, Paul. (1992). Os contos de Machado de Assis: Mais do que sonha a filosofia. Porto Alegre: Movimento.

Doane, Mary Ann. (1991). Femmes Fatales: Feminism, Film Theory, Psychoanalysis. New York: Routledge.

Duncan, Cynthia. (2010). Unraveling the Real: The Fantastic in Spanish-American Ficciones. Philadelphia: Temple UP.

Emonds, Friederike B. (1997). Femme Fragile. The Feminist Encyclopedia of German Literature (p. 165-66) (Friederike Eigler and Susanne Kord Eds.) Westport: Greenwood.

Fernandes, Marcelo. (2003). Machado de Assis: Quase-macabro. Poiésis: Literatura, Pensamento \& Arte. 85. Retrieved from http://www.netterra.com. br/poiesis/85/machado_de_assis.htm. Accessed September/2015.

Ferreira-Pinto, Cristina. (2004). Gender, Discourse, and Desire in TwentiethCentury Brazilian Women's Literature. West Lafayette: Purdue UP.

Finney, Gail. (1991). Women in Modern Drama: Freud, Feminism, and European Theater at the Turn of the Century. Ithaca: Cornell UP. 
Fitz, Earl E. (2015). Machado de Assis and Female Characterization: The Novels. Lewisburg: Bucknell UP.

Gledson, John. (1984). The Deceptive Realism of Machado de Assis: A Dissenting Interpretation of Dom Casmurro. Liverpool: Francis Cairns.

. (2006). O machete e o violoncelo: Introdução a uma antologia dos contos de Machado de Assis (p. 35-69) (Fernando Py Trans.). Por um novo Machado de Assis: Ensaios. São Paulo: Companhia das Letras.

Gomes, Eugênio. (1967). O enigma de Capitu: Ensaio de interpretação. Rio de Janeiro: José Olympio.

Hake, Sabine. (1997). Femme Fatale. The Feminist Encyclopedia of German Literature (p. 163-165). (Friederike Eigler and Susanne Kord Eds.). Westport: Greenwood.

Hentz, Isabel Cristina. (2011). Filhos legítimos da ciência: Os homens de ciência nos contos de Machado de Assis (1870-1884). Simpósio Nacional de História. ANPUH, São Paulo. Jul. 2011. Retrieved from http://www.snh2011.anpuh.org/ resources/anais/14/1300916313 ARQUIVO textocompletoANPUH2011.pdf Accessed September/2015.

Jackson, Rosemary. (1981). Fantasy: The Literature of Subversion. New York: Methuen. Lisboa, Maria Manuel. (1996). Machado de Assis and Feminism: Re-reading the Heart of the Companion. Lewiston: Edwin Mellen P.

Lula, Darlan de Oliveira Gusmão. (2005). Machado de Assis e o gênero fantástico: Um estudo de narrativa machadianas. Mathesis. Universidade Federal de Juiz de Fora. Retrieved from http://www.santoandre.sp.gov.br/pesquisa/ ebooks/355301.PDF Accessed September/2015.

Machado de Assis, Joaquim Maria. (1859). Bagatela. Coleção Digital Machado de Assis. Portal Domínio Público, Ministério da Educação, Núcleo de Pesquisa em Informática, Literatura e Linguística. Retreived from http:// machado.mec.gov.br/images/stories/pdf/contos/macn136.pdf. Accessed September/2015

. (1862). O país das quimeras. Marta de Senna (Ed.). CNPq, FAPERJ, Fundação Casa de Rui Barbosa. Retreived from http://machadodeassis.net/ hiperTx romances/obras/contosavulsos.htm. Accessed September/2015. - (1864). O anjo das donzelas. Marta de Senna (Ed.). CNPq, FAPERJ, 
Fundação Casa de Rui Barbosa. Retreived from http://machadodeassis.net/ hiperTx romances/obras/contosavulsos.htm. Accessed September/2015.

. (1866). Uma excursão milagrosa. Marta de Senna (Ed.). CNPq, FAPERJ, Fundação Casa de Rui Barbosa. Retreived from http:// machadodeassis.net/hiperTx_romances/obras/contosavulsos.htm Accessed September/2015.

(1869). O anjo Rafael. Marta de Senna (Ed.). CNPq, FAPERJ, Fundação Casa de Rui Barbosa. Retreived from http:// machadodeassis.net/hiperTx romances/obras/contosavulsos2.htm Accessed September/2015.

(1870). O Capitão Mendonça. Marta de Senna (Ed.). CNPq, FAPERJ, Fundação Casa de Rui Barbosa. Retreived from http:// machadodeassis.net/hiperTx romances/obras/contosavulsos2.htm Accessed September/2015.

. (1870). A vida eterna. Coleção Digital Machado de Assis. Portal Domínio Público, Ministério da Educação, Núcleo de Pesquisa em Informática, Literatura e Linguística. Retreived from http://machado.mec.gov.br/images/stories/pdf/ contos/macn033.pdf. Accessed September/2015.

. (1871). Mariana. Marta de Senna (Ed.). CNPq, FAPERJ, Fundação Casa de Rui Barbosa. Retreived from http://machadodeassis.net/hiperTx romances/ obras/contosavulsos2.htm. Accessed September/2015.

. (1872). Rui de Leão. Marta de Senna (Ed.). CNPq, FAPERJ, Fundação

Casa de Rui Barbosa. Retreived from http://machadodeassis.net/hiperTx romances/obras/contosavulsos3.htm. Accessed September/2015.

- (1873). Decadência de dois grandes homens. Marta de Senna (Ed.). CNPq, FAPERJ, Fundação Casa de Rui Barbosa. Retreived from http:// machadodeassis.net/hiperTx romances/obras/contosavulsos3.htm. Accessed September/2015.

. (1874). Os óculos de Pedro Antão. Marta de Senna (Ed.). CNPq, FAPERJ, Fundação Casa de Rui Barbosa. Retreived from http://machadodeassis.net/ hiperTx romances/obras/contosavulsos4.htm.Accessed September/2015. . (1875). A chinela turca. Marta de Senna (Ed.). CNPq, FAPERJ, Fundação 
Casa de Rui Barbosa. Retreived from http://machadodeassis.net/hiperTx romances/obras/papeisavulsos.htm. Accessed September/2015.

. (1875). Um esqueleto. Marta de Senna (Ed.). CNPq, FAPERJ, Fundação

Casa de Rui Barbosa. Retreived from http://machadodeassis.net/hiperTx romances/obras/contosavulsos4.htm. Accessed September/2015.

. (1876). Sem olhos. Marta de Senna (Ed.). CNPq, FAPERJ, Fundação Casa de Rui Barbosa. Retreived from http://machadodeassis.net/hiperTx romances/ obras/contosavulsos5.htm. Accessed September/2015.

(1876, 1882). Uma visita de Alcibíades. Marta de Senna (Ed.). CNPq, FAPERJ, Fundação Casa de Rui Barbosa. Retreived from http://machadodeassis. net/hiperTx romances/obras/papeisavulsos.htm. Accessed September/2015.

(1879). A nova geração. Coleção Digital Machado de Assis. Portal Domínio Público, Ministério da Educação, Núcleo de Pesquisa em Informática, Literatura e Linguística. Retreived from http://machado.mec.gov.br/images/stories/pdf/critica/mact29.pdf Accessed September/2015.

. (1881). Memórias póstumas de Brás Cubas. Marta de Senna (Ed.). CNPq, FAPERJ, Fundação Casa de Rui Barbosa. Retreived from http://machadodeassis. net/hiperTx romances/obras/brascubas.htm. Accessed September/2015.

. (1881). A mulher pálida. Marta de Senna (Ed.). CNPq, FAPERJ, Fundação Casa de Rui Barbosa. Retreived from http://machadodeassis.net/hiperTx romances/obras/contosavulsos6.htm. Accessed September/2015.

. (1882). O espelho. Marta de Senna (Ed.). CNPq, FAPERJ, Fundação Casa de Rui Barbosa. Retreived from http://machadodeassis.net/hiperTx romances/ obras/papeisavulsos.htm. Accessed September/2015.

. (1882). O imortal. Marta de Senna (Ed.). CNPq, FAPERJ, Fundação Casa de Rui Barbosa. Retreived from http://machadodeassis.net/hiperTx romances/ obras/contosavulsos6.htm. Accessed September/2015.

. (1883). A igreja do diabo. Marta de Senna (Ed.). CNPq, FAPERJ, Fundação Casa de Rui Barbosa. Retreived from http://www.machadodeassis.net/hiperTx romances/obras/Historiassemdat a.htm Accessed September/2015.

. (1884). As academias de Sião. Marta de Senna (Ed.). CNPq, FAPERJ, 
Fundação Casa de Rui Barbosa. Retreived from http://www.machadodeassis. net/hiperTx romances/obras/Historiassemdata.htm. Accessed September/2015.

(1884). A cartomante. Marta de Senna (Ed.). CNPq, FAPERJ, Fundação Casa de Rui Barbosa. Retreived from http:// machadodeassis.net/hiperTx romances/obras/variashistorias.htm Accessed September/2015.

(1884). A segunda vida. Marta de Senna (Ed.). CNPq, FAPERJ, Fundação Casa de Rui Barbosa. Retreived from http://www. machadodeassis.net/hiperTx romances/obras/Historiassemdata.htm Accessed September/2015.

(1885). A causa secreta. Marta de Senna (Ed.). CNPq, FAPERJ, Fundação Casa de Rui Barbosa. Retreived from http:// machadodeassis.net/hiperTx romances/obras/variashistorias.htm Accessed September/2015.

- (1892). Um sonho e outro sonho. Marta de Senna (Ed.). CNPq, FAPERJ, Fundação Casa de Rui Barbosa. Retreived from http:// machadodeassis.net/hiperTx romances/obras/contosavulsos10.htm Accessed September/2015.

(1894). Missa do galo. Marta de Senna (Ed.). CNPq, FAPERJ, Fundação Casa de Rui Barbosa. Retreived from http:// machadodeassis.net/hiperTx romances/obras/paginasrecolhidas.htm Accessed September/2015.

(1899). Dom Casmurro. Marta de Senna (Ed.). CNPq, FAPERJ, Fundação Casa de Rui Barbosa. Retreived from http://www. machadodeassis.net/hiperTx romances/obras/domcasmurro.htm Accessed September/2015.

(1899). Quincas Borba. Marta de Senna (Ed.). CNPq, FAPERJ, Fundação Casa de Rui Barbosa. Retreived from http:// machadodeassis.net/hiperTx romances/obras/quincasborba.htm Accessed September/2015.

- (1904). Esaú e Jacó. Marta de Senna (Ed.). NPq, FAPERJ, 
Fundação Casa de Rui Barbosa. Retreived from http://www. machadodeassis.net/hiperTx romances/obras/esauejaco.htm Accessed September/2015.

Magalhães Júnior, Raimundo. (1973). Preface. Machado de Assis: Contos fantásticos (p. 7-9). Rio de Janeiro: Bloch.

Marafante, Laura Geraldo Martins. (2014). As personagens femininas autômatas em O Capitão Mendonça de Machado de Assis, e O homem da areia, de Hoffman: Uma análise comparativa. Colóquio Internacional de Estudos Linguísticos e Literários. Universidade Estadual de Maringá, Maringá. Retrieved from http:// cielli2014.com.br/media/doc/8a28aad9e2d53fa7b4d90fcc3a73fa30.pdf. Accessed September/2015.

Pietrani, Anélia Montechiari. (2000). O enigma mulher no universo masculino machadiano. Niterói: Editora da Universidade Federal Fluminense.

Rabkin, Eric S. (1976). The Fantastic in Literature. Princeton: Princeton UP.

Rodrigues, Carla. (2008). Traidora. Quem é Capitu? (p. 61-74) (Alberto Schprejer Ed.). Rio de Janeiro: Nova Fronteira S.A.

Simões Júnior, Álvaro Santos. (2009). Preface. Machado de Assis no Jornal das Famílias (p. 15-18). São Paulo: Nankin.

Stein, Ingrid. (1984). Figuras femininas em Machado de Assis. Rio de Janeiro: Paz e Terra. Tavares, Braulio. (2003). Páginas de Sombra: Contos fantásticos brasileiros. Rio de Janeiro: Casa da Palavra.

Teles, Adriana da Costa. (2013). Viver e morrer de amor em O anjo das donzelas. (v.6, n.12, p. 154-166). Machado de Assis em linha.

Todorov, Tzvetan. (1975). The Fantastic: A Structural Approach to a Literary Genre. Richard Howard (Trans.). Ithaca: Cornell UP. 